\title{
Studies on Validity of Incentive Evaluation of Col- lege English Teaching
}

\author{
GUO Han-ying \\ Department of foreign languages \& tourism \\ Hainan College of Software Technology \\ Qionghai 571400, China \\ katherine770205@sina.com
}

\author{
JIANG Xiu-juan \\ Department of foreign languages \& tourism \\ Hainan College of Software Technology \\ Qionghai 571400, China \\ 79839006@qq.com
}

\begin{abstract}
In the context of work-integrated learning mode, the reform of college English teaching has been made progress. High affective filter and deficiency of study strategies drive incentive evaluation as an essential condition to attain teaching objectives. To enhance the effect, efforts should be focused on the rationality of tasks, the entirety, diversity and timeliness of evaluation.
\end{abstract}

Keywords—college English teaching; incentive evaluation; validity; rationality

\section{INTRODUCTION}

Aiming at cultivating the college students' competence, the work-integrated mode was adopted, which has impulse the reform of college English teaching and taken effect on teaching. But it is the validity of incentive evaluation that determines the result of teaching because of the characteristic of college students caused by prejudice traditional culture has put on vocational education and the university expansion.

\section{NECESSITY OF INCENTIVE EVALUATION}

\section{A. Innovation and Features of Incentive Evaluation}

Incentive evaluation refers to a comprehensive multievaluation system or incentive mechanism, by which subjects of evaluation get timely feedback and adjust the system or mechanism in order to inspire the evaluation objects with selfconfidence and desire to learn to give full play of their competence. Focusing on co-constructing evaluation and encouraging the evaluation objects, incentive evaluation is originated from the Fourth Generation Evaluation differs from what came before it, general feature of which is to focus on comparing all the objects according to a standard predetermined quantified evaluation $^{[1]}$. It has no standard and keeps changing and creating with tasks, objects, phases, and evaluation result. Incentive evaluation places more emphasis on the interest and practicability of the designed tasks and team spirit to maintain attraction of English learning, on the entirety and diversity to strengthen intensity and enlarge range, that is to drive students more active and positive in English learning and to attract more students to join in, and the timeliness to upgrade the system immediately.

\section{B. Necessity and Positive Effect of Incentive Evaluation on college students' learning}

In the process of daily teaching, the writer has observed two parallel classes, Class A that was adopted incentive evaluation and Class B that wasn't, and found the results of the two ones quite different. After three weeks' running-in period from excitement out of curiosity to losing interest because of bad learning habit and languor, $91.6 \%$ of Class A concentrate themselves on lessons most of the time, while $74.4 \%$ of Class B can't focus on lessons but novels or mobile phones although stopped and warmed by the teacher constantly. The writer holds that is mainly because of the characteristic of college students that is the bad lack of clear object of learning, selfconfidence trusting in teachers, and learning strategies. What's more, college English, as a basic course, is so scarcely relevant to the students' major and the skills they need for their future positions that good relationship between teachers and students and reasonable task design play a little role in urging them to keep on except ones with good learning habit and enough knowledge. They prefer playing mobile phones or sleeping to listening to the teacher because they don't believe in themselves and teachers. They aren't willing to try their best because they don't have chance to have a look at the outlook. Basically they need to crash these negative emotions to have chance to learn about English learning and move on, they need stimuli to drive them to move on and rely on themselves.

Incentive evaluation is to use the method of evaluation to reduce affective filter, inspire students to improve the "intake" of "the comprehensible input"[2], and to develop students" learning strategies and cultivate their emotional quotient. Krashen's affective filter hypothesis holds that certain emotions, such as anxiety, self-doubt, and mere boredom interfere with the process of acquiring a second language. They function as a filter between the speaker and the listener that reduces the amount of language input the listener is able to understand. These negative emotions prevent efficient processing of the language input ${ }^{[3]}$. The hypothesis further states that the blockage can be reduced by sparking interest, provided lowanxiety environments, and bolstered the learner's self-esteem. It has been proved that a person would play $80 \%-90 \%$ and even more of his competence when impulse, otherwise only $20 \%-30 \%{ }^{[4]}$. Having been marginalized gradually by examoriented education system, college students' affective filter 
would be very high, which needs renovating. Effective incentive evaluation encourage students to explore themselves, analyze on their own, participate in activities actively in team and give affirmative and timely evaluations, which helps establish reliable relationship between teachers and students, create low-anxiety and even light learning atmosphere, stimulate students' interest in English learning, and make them learn the learning rules, develop good learning habit and strategies and keep on to gain persistence and self-confidence. And that is one of necessary conditions to guarantee good learning results in a long run.

\section{THE EXPLORATION OF THE VALIDITY OF InCENTIVE Evaluation}

Having reflected on teaching practice, the writer holds that the validity of incentive evaluation can be enhanced through the following aspects:

\section{A. Rationality of the Designed Tasks}

Getting to know students and making full sense of what you teach are the premise that makes the current exploration possible and valuable.

\section{1) Establish good mutual relationship}

Reliable mutual relationship is a prerequisite to design teaching methods and evaluation in consideration of the features of college students' EQ. It's not teaching but stimulating, awakening, and encouraging that is essential of education. You have to help them appreciate themselves, get relaxed and look straight at teachers and English learning without fear and hesitation. They must be told that they can make it because a language is to be used, not merely to be tested, and that's just what they're good at. They like practicing, only by which speech competence can be acquired. After the running-in period, they also need more encouraging and appreciating and trusting than criticizing. And more and more opportunities must be created for them to gain self-confidence from the course and trust from the teacher.

2) Comprehend teaching contents, knowing about students, design rational tasks.

According to difference of the various individual, tasks have to be decomposed or integrated based on Krashen's input hypothesis, which is that learners progress in their knowledge of the language when they comprehend language input that is slightly more advanced than their current level. Krashen called this level of input " $i+1$ "[5], where " $i$ " represents previously acquired linguistic competence and extra-linguistic knowledge, $\mathrm{e}$, the hypothesis claims that we move from " $\mathrm{i}$ " to " $\mathrm{i}+1$ " by understanding input that contains " $i+1$ ". Extra-linguistic knowledge includes our knowledge of the world and of the situation, that is, the context. The " +1 " represents new knowledge or language structures that we should be ready to acquire. To learn their current level, design interest and practical tasks by proper practicing in real context, and give timely and incentive evaluation are the three keys to attain " $i+1$ " comprehend language input.

Take "I want..." for example:
TABLE I. DECOMPOSED TASKS AND EVALUATIONS

\begin{tabular}{|l|l|l|}
\hline Steps & Decomposed Tasks & Evaluations \\
\hline 1 & $\begin{array}{l}\text { Show pictures and say: an apple, an ice } \\
\text { cream, a pack of tissue, a bottle of } \\
\text { soda...; repeat and practice in groups in } \\
\text { 2mins: answer race }\end{array}$ & $\begin{array}{l}\text { PK in groups,the } \\
\text { winner gain one } \\
\text { point. }\end{array}$ \\
\hline 2 & $\begin{array}{l}\text { Practice in pairs in 1min: say: "I } \\
\text { want..." according to the pictures } \\
\text { shown }\end{array}$ & $\begin{array}{l}\text { The first 10 guys gain } \\
\text { one point. }\end{array}$ \\
\hline 3 & $\begin{array}{l}\text { Practice in pairs in 1min: say: "I } \\
\text { want...and..." according to the pictures } \\
\text { shown }\end{array}$ & $\begin{array}{l}\text { One representative } \\
\text { blurt out, the group } \\
\text { gain one point. }\end{array}$ \\
\hline
\end{tabular}

A pattern can be consolidated as a semantic unit as the above by practicing and playing games no matter how complicated it is. As long as the tasks are interesting and practical enough for students, they are willing to take part in the games and gain points by themselves or with the help of others. Therefore, avoiding explaining grammar points is rather important. In teaching practice, the tasks can be decomposed or integrated according to the performances of the students.

Acquiring a second language in groups is also very important. In a team, advanced ones help others, which relieve pressure from the teacher but strengthen the encouragement and supervision from companions, offering space for them to make self-adjustment to cooperate with others. That will help them form self-consciousness and team spirit and construct learning competence to self-regulate. Creating real context is another key to get students relaxed by emphasizing one point that they are just playing.

\section{B. Entirety of Evaluation}

\section{1) Lateral entirety}

Stimulate everyone to take part in activities in relaxing atmosphere. Make sure every member in a group take turns to stand up for their team. After class, group leaders supervise every member to finish assignments (see Table II). Group leaders arrange everyone a task in pre-module activities and experiential activities in turn according to what they are skilled in, ensuring everyone has chance to exert their speciality, enhancing self-confidence and sense of belonging.

TABLE II. OUT-CLASS EVALUATION

\begin{tabular}{|c|c|c|c|c|c|c|c|c|c|c|c|c|c|c|}
\hline Perf & & lance Ev & alus & tio & $\mathrm{F}$ & rn & 2 & Gr & up & 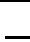 & $: V$ & Tork & k Division 8 & Score \\
\hline Topic & & $\begin{array}{c}\text { Pre- } \\
\text { module } \\
\text { Activity }\end{array}$ & & & ral & $i s s i$ & $n n$ & en & & & $\begin{array}{c}w r i \\
\text { ass } \\
n n \\
n\end{array}$ & & $\begin{array}{c}\text { Experiential } \\
\text { Activity }\end{array}$ & $\begin{array}{c}\mathrm{TP} \\
\text { (total } \\
\text { points) }\end{array}$ \\
\hline & & & 1 & 2 & 3 & 4 & 5 & 6 & 7 & 8 & 1 & 2 & & \\
\hline Cont & & & & & & & & & & & & & & \\
\hline & & & & & & & & & & & & & & \\
\hline Gro & & & & & & & & & & & & & & \\
\hline up & & & & & & & & & & & & & & \\
\hline $\begin{array}{l}\mathrm{Me} \\
\mathrm{mb}\end{array}$ & & & & & & & & & & & & & & \\
\hline er & & & & & & & & & & & & & & \\
\hline & & & & & & & & & & & & & & \\
\hline Sumn & & & & & & & & & & & & & & \\
\hline $\begin{array}{r}\text { Rem } \\
\text { activ }\end{array}$ & & $\begin{array}{l}\text { One g } \\
\text { Each } \\
\end{array}$ & & & & & & & & & & & $\begin{array}{l}\text { ivity an } \\
\text { plete on }\end{array}$ & $\begin{array}{l}\text { t-class } \\
\text { he as- }\end{array}$ \\
\hline
\end{tabular}


Various skills have to be stressed, practiced and improved especially listening and speaking skills. In phased evaluations, such as final-examination, the ratio of listening: speaking: reading and writing can be 3:2:3. The speaking part can be reciting a dialogue, making up a new dialogue, singing songs or giving a short speech. Content, pronunciation and intonation must be considered comprehensively when an assessment is given.

In a term, evaluation includes different factors that embody the performance of students: attendance $10 \%+$ performance $20 \%$ + project $20 \%$ + final-term examination $50 \%$.

\section{2) Vertical entirety}

Evaluation must be diachronic throughout whole module or whole term. In a module, it includes: pre-module activity + in-class activities + after-class assignments + experiential activity. Pre-module activity is generally designed to prepare students to get to know the background or context or some relevant topics of this module. Experiential activity is designed to consolidate what they have learned this module through playing roles in several interrelated dialogues and then make a video, hoping that students could get so familiar to the expressions of this module that they can acquire them as one semantic unit. (see Table III).

TABLE III. EXPERIENTIAL ACTIVITY EVALUATION

\begin{tabular}{|l|l|l|l|l|l|l|l|l|}
\hline \multicolumn{7}{|c|}{ Performance Evaluation Form 3 (Experiential Activity: } \\
\hline Group (2-4-5 points) \\
\hline \multicolumn{2}{|c|}{ G1 } & G2 & G3 & G4 & G5 & G6 & & Individual (3 points) \\
\hline Division of work & & & & & & & Group leader & (see Form 2) \\
\hline story & & & & & & & best director & \\
\hline action & & & & & & & best actor/actress & \\
\hline pronunciation & & & & & & & best speaker & \\
\hline design of scene & & & & & & & best stage designer & \\
\hline film & & & & & & & best photographer & \\
\hline
\end{tabular}

\section{Diversity of Evaluation}

There is no fixed ways to teach. Evaluation needs creative things and the participation of students to keep students excited.

\section{1) Various elements}

Arrangement, language using, cooperation, selfadjustment, question and creation all are elements of evaluation (see Table II \& III).

Take experiential activity for example. One of the common ways to review and consolidate what have been learned is to video what they make up after the whole module learning, that is, they have to design a context, make a or several new dialogues, then put on a play. The videos of the plays will be judged and commented by teachers and students in or after the class even on line from different perspectives.

\section{2) Various subjects}

Teacher and students design evaluation together and estimate together, which can cultivate their self-consciousness and team spirit (see Table III and Table IV). For example, stu- dents' representatives are appointed in turn to check if most of another group completes the oral assignments at the very beginning of each period, which guarantees as many students to join as possible and saves much time. And actually Table III was designed with the help of students, and Table IV needs teacher and students to work together to finish.

TABLE IV. MODULE EVALUATION

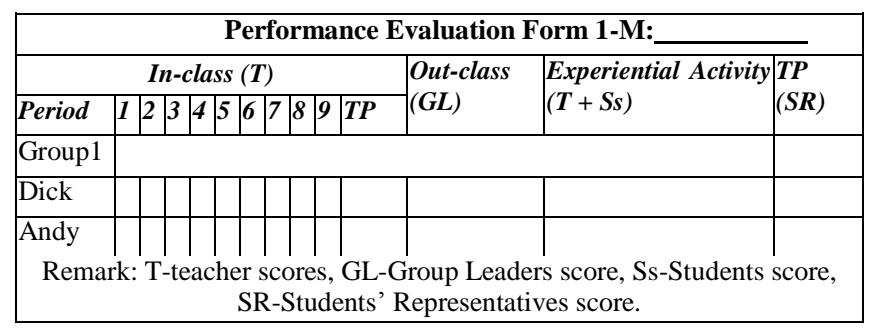

Students' taking part in evaluation is to give those rights and opportunities to learn as much about their own performance as possible and to realize that they have answered for what they did, which drive them self-reflect and self-adjust to improve their condition.

\section{3) Various demands during different phases}

Gradually raise the standard of evaluation is necessary. In the running-in period, the priority of evaluation is to satisfy everyone's desire to gain recognition for their effort, thereby establishing harmonious teacher-student relationship, but the priority is to strengthen learning results after this period. The standard must be adjusted all the time according the students' level and mental state. What's more, don't give each one a chance; otherwise, they wouldn't try their best to compete against each other. During the third phase, if possible, the priority is to integrate tasks gradually and let students practice decomposing a task and fulfills it on their own.

\section{Timeliness of Evaluation}

Evaluation must be timely so as to help teachers learn results of teaching and learning immediately and do some adjustment as quickly as possible. At the same time seduce students to know it by words, and let them have to self-reflect; self-adjust so as to form good learning habit.

As shown in Table IV, every module has its topic and the teacher has to fill in the blank in "Performance Evaluation Form 1M:_ ". It is often finished in 9 weeks or so. The teacher scores their performance when students have finished their tasks at class every period and calculates the results of $\boldsymbol{I n}$ class weekly. Group leaders score the assignments the moment they have checked them before the deadline if there is one. The students can check up on the in-class results from the teacher and the out-class results from their group leaders of every week even anytime. If anyone isn't satisfied with his or her own performance marks, they can inquire about it or adjust themselves as quickly as they can and behave more actively in class and more industriously after class.

Before review section, every group has to hand in their videos. All videos are watched, commented and evaluated before deadlines (see Table III). Sometimes some other teachers and students can be invited to take part into the evaluation 
at class or even on line, which makes the evaluation seem much more exciting and objective, which drives students more excited to work harder than before.

Then come the most important part of evaluation. When the module is finished, the teacher and student representatives cooperate and calculate the marks of the whole module after class (see Table IV). The teacher announces the results by QQ if allowed by students. The first several highest mark holders can be appointed to be the group leaders during the coming period of time of next module learning. The group leaders have rights to choose anyone who are willing to be one member of this group. Group leaders will get extra marks depending on their work to organize members and coordinate the work of every activity. The students who get invited by some or several group leaders are expected to be encouraged and behave better, while most of the ones who aren't invited will be stimulated and begin to work harder. The teacher can try to make everyone belong to a group after getting the promises from the unwanted ones that they will try their best to study later on. If there are still some ones who aren't accepted or aren't willing to join others, they could form one team and choose one group leader of their own. Or, the teacher appoints several lowest mark holders to be the group leaders, and give their chance to know about team spirit, sense of responsibility and the work about organizing and coordinating, which help establish self-confidence, develop self-discipline and make them get progress. All these work have to be finished timely before the next module starts.

\section{Analysis on the TEACHING PRACTICE}

As mentioned in Part II, the writer has adopted incentive evaluation in the process of teaching every module in Class A. Performance Evaluation Form 1, 2, 3 are a whole evaluation system to encourage as many students to acquire foreign language effectively as possible.

At the very beginning of the cooperation between a teacher and students, so called "running-in period", decomposing the tasks, make them easier and more interesting are the focus of the teaching job. At the same time, students' current level and interests must be learned about. In order to attract students, there are some principles during this phase: anyone who takes part into activities, whatever he or she is active or passive, will gain marks once; gain twice if he or she gives the right answer; and gain triple if he or she does it beautifully or creatively, aiming at telling students that: first, English learning is also interesting and creative and worth trying; second, you can do it well if you like; third, you'll gain as long as you try. Through high-intensity but interesting practicing and evaluating, students can acquire language as well as get a great deal of chance to develop the learning habit of listening to the teacher at class, raising questions anytime without hesitation, joining in the group activities actively.

After the first phase during which teacher and students have established comparatively reliable relationship, some students have begun to like this course, while others has got tired of the new teacher, new classmates and new methods because of languor and lack of persistence. Some principles need changing to keep the course attractive: a) Encourage the ones who are active. Anyone who is active will gain marks once no matter the answer he gives is right or wrong; gain twice if the answer is right; the ones who is passive will gain marks once if he is right, gain zero if he is wrong. b) Invite students to take part in the design of evaluation and carry out the evaluation together. Giving students chances to design as a subject of evaluation is to let them think in teacher's shoes, and to let them judge themselves, they have henceforth begun to self-evaluate and self-adjust.

During the third phase, the priority is to develop students learning strategies to study on their own. The teacher integrates the tasks gradually and enhances the difficulty and frequency gradually to let students fulfill tasks on their own without teachers' help. They have to analyze tasks, discuss and cooperate, and adjust themselves to complete the task step by step by themselves. Thus, students would develop learning strategies to study on their own and keep learning by themselves after the whole school year's learning.

After a long-run practice, in Class A about 9/10 students are active to join in activities and 3/4 students are able to fulfill complete tasks in groups on their own.

\section{CONCLUSION}

The writer holds that it has been proved that rationality of designed tasks, the entirety, diversity and timeliness of evaluation are the four perspectives from which a teacher can establish a valid incentive evaluation to lower the students' affective filter and let them develop learning strategies and improve the "intake" of comprehensible input and acquire a second language.

\section{ACKNOWLEDGMENT}

I would like to thank Liu Shixiang for his encouragement. I am also grateful to $\mathrm{Wu}$ Jingling and Wang Ruijiao for their generous share of teaching experience with me.

\section{REFERENCES}

[1] Chen Yulin, and Yu Shuling, "Improve College Teaching Evaluation on 'the Fourth Generation Evaluation"', Journal of Daqing College, pp 8587, February 1997.

[2] Jiang Yulin, "On Project-driven Teaching Reform of Course of Practice of International Freight Forwarding," in Journal of Wuhan Polytechnic, vol. 6, 2013, pp. 63-67.

[3] Krashen, S.Explorations in Language Acquisition and Use. Portsmouth: Heinemann, 2003.

[4] Krashen, S.Explorations in Language Acquisition and Use. Portsmouth: Heinemann, 2003.

[5] Krashen, S.Explorations in Language Acquisition and Use. Portsmouth: Heinemann, 2003. 